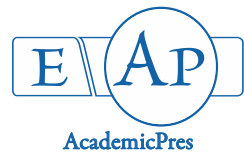

\title{
Differential Growth Responses of Wheat Seedlings to Elevated $\mathrm{CO}_{2}$
}

\author{
Hamid R. ESHGHIZADEH*, Morteza ZAHEDI, \\ Samaneh MOHAMMADI
}

Isfahan University of Technology, College of Agriculture, Department of Agronomy and Plant Breeding, Isfahan,

Iran; hr.eshghizadeh@cc.iut.ac.ir ("correspondingauthor);mzahedi@cc.iut.ac.ir; SamaMoh1367@gmail.com

\begin{abstract}
Intraspecific variations in wheat growth responses to elevated $\mathrm{CO}_{2}$ was evaluated using 20 Iranian bread wheat (Triticum aestivum $\mathrm{L}$.) cultivars. The plants were grown in the modified Hoagland nutrient solution at a greenhouse until 35 days of age using two levels of $\mathrm{CO}_{2}\left(\sim 380\right.$ and $\left.700 \mu \mathrm{mol} \mathrm{mol}^{-1}\right)$. The shoot and root dry weights of the wheat cultivars exhibited average enhancements of $17 \%$ and $36 \%$, respectively, under elevated $\mathrm{CO}_{2}$. This increase was associated with higher levels of chlorophyll $a(25 \%)$, chlorophyll $b(21 \%)$, carotenoid $(30 \%)$, leaf area $(54 \%)$ and plant height $(49.9 \%)$. The leaf area $(\mathrm{r}=$ $\left.0.69^{*}\right)$, shoot $\mathrm{N}$ content $\left(\mathrm{r}=0.62^{\prime \prime}\right)$, plant height $\left(\mathrm{r}=0.60^{\prime \prime}\right)$ and root volume $\left(\mathrm{r}=0.53^{\circ}\right)$ were found to have important roles in dry matter accumulation of tested wheat cultivars under elevated $\mathrm{CO}_{2}$ concentration. However, responses to elevated $\mathrm{CO}_{2}$ were considerably cultivar-dependent. Based on the stress susceptibility index (SSI) and stress tolerance index (STI), the wheat cultivars exhibiting the best response to elevated $\mathrm{CO}_{2}$ content were 'Sistan', 'Navid', 'Shiraz', 'Sepahan' and 'Bahar', while the ones with poor responses were 'Omid', 'Marun', 'Sorkhtokhm' and 'Tajan'. The findings from the present experiment showed significant variation among the Iranian wheat cultivars in terms of their responses to elevated air $\mathrm{CO}_{2}$, providing the opportunity to select the most efficient ones for breeding purposes.
\end{abstract}

Keywords: climate change; $\mathrm{CO}_{2}$ enrichment; genetic diversity; Nitrogen use efficiency; stress susceptibility index Abbreviations: NUE: Nitrogen use efficiency; SSI: Stress susceptibility index; STI: Stress tolerance index

\section{Introduction}

Wheat is one of the most important crops as it provides approximately $20 \%$ of the energy and $25 \%$ of the protein requirements of the world's population of 6.6 billion (Pocketbook, 2015; Reddy and Hodges, 2000). It also ranks first among cultivated field crops in Iran with an average per capita consumption of about $220 \mathrm{~kg}$, consumed both directly and indirectly (Khajehpour, 2013). A 60\% increase is imminent in the demand for wheat by a world population of 9 billion by 2050 (Fischer et al., 2014). Clearly, any contribution to greater production of wheat and its reduced production costs will benefit human food security.

Based on the records of monitoring stations at Mauna Loa in Hawaii, the annual mean growth rate of carbon dioxide concentration increased from 0.94 in 1959 to 3.05 $\mu \mathrm{mol} \mathrm{mol}{ }^{-1} / \mathrm{yr}$, whereas the atmospheric $\mathrm{CO}_{2}$ has risen from 315 to $400 \mathrm{mmol} \mathrm{mol}^{-1}$ over the past 56 years (Tans, 2016).

Current projections indicate that atmospheric $\mathrm{CO}_{2}$ will continue to rise to $450-1.000 \mu \mathrm{mol} \mathrm{mol}{ }^{-1}$ by the year 2100 (IPCC, 2014). Increasing carbon dioxide concentration improves photosynthesis in $\mathrm{C}_{3}$ plants such as wheat via prevention of photorespiration; thus, wheat yield is expected to increase under elevated $\mathrm{CO}_{2}$ assuming that other growth factors remain within optimal limits (Amthor, 1997). Bourgault et al. (2013) found that average leaf area of wheat plants was increased by $30 \%$ under elevated $\mathrm{CO}_{2}$ concentration of $700 \mu \mathrm{mol} \mathrm{mol}^{-1}$ compared with its normal ambient level $\left(400 \mu \mathrm{mol} \mathrm{mol}^{-1}\right)$. Pal et al. (2005) reported that wheat plants recorded a greater photosynthetic rate, plant height, leaf surface area and plant dry mass at all growth stages $(40,60$, and $90 \mathrm{~d}$ after sowing) under an elevated $\mathrm{CO}_{2}$ of $600 \pm 50 \mu \mathrm{mol} \mathrm{mol}{ }^{-1}$ than those grown under the ambient $\mathrm{CO}_{2}$ of $350 \pm 50 \mathrm{umol} \mathrm{mol}^{-1}$.

Although increasing concentrations of $\mathrm{CO}_{2}$ are expected to have a positive effect on the performance of $\mathrm{C}_{3}$ crops, a wide variation is observed within the species. Amthor (2001) reviewed 50 studies investigating the effects of carbon dioxide on wheat growth to conclude that, regardless of the approach adopted to control $\mathrm{CO}_{2}$, a great variation, ranging from -20 to $+250 \%$, can be observed in the influence $\mathrm{CO}_{2}$ on grain yield. Musgrave and Strain (1988) investigated the effect of $\mathrm{CO}_{2}$ enrichment ( 1.000 vs $350 \mu \mathrm{mol}{ }^{-1}$ ) on two wheat cultivars in a growth chamber 
and reported that growth and assimilation rates were more pronounced in 'Yecora Rojo' than in the 'Sonoita' cultivar. Seneweera et al. (2010) evaluated eight wheat cultivars in the Australian Grains Free Air Carbon Dioxide Enrichment (AGFACE) facility and showed that the largest (by 30\%) and smallest (4\%) relative increases in dry mass due to $\mathrm{CO}_{2}$ enrichment $\left(550\right.$ vs $380 \mu \mathrm{mol} \mathrm{mol}^{-1}$ ) were observed in the 'Gladius' and 'Janz' cultivars, respectively.

Mitterbauer et al. (2014) reported significant differences in the responses to elevated $\mathrm{CO}_{2}\left(\sim 700 \mathrm{vs} \sim 400 \mu \mathrm{mol} \mathrm{mol}^{-}\right.$ $\left.{ }^{1}\right)$ among 101 barely genotypes grown in open-top field chambers. In their experiment, the changes in grain yield ranged from -48 to $+175 \%$ and those in the aboveground biomass varied from +45 to $+166 \%$. Uprety et al. (2003) examined the influence of elevated $\mathrm{CO}_{2}$ concentrations of $575-620 \mu \mathrm{mol} \mathrm{mol}{ }^{-1}$ on two rice varieties and concluded that the positive effects on most traits were more pronounced in 'Pusa Basmati-1' than in the 'Pusa-677' cultivar. Kazemi et al. (2018) reported that the effects of elevated $\mathrm{CO}_{2}$ on the growth of rice plants depended on both variety and the salinity level.

Although variation in growth response to elevated $\mathrm{CO}_{2}$ among wheat cultivars is documented, no information is yet available in this regard on Iranian bread wheat cultivars. Accordingly, the present study was conducted to evaluate the growth responses of Iranian bread wheat cultivars to increasing atmospheric $\mathrm{CO}_{2}$.

\section{Materials and Methods}

\section{Plant material}

The local names and some agronomic characteristics of the studied wheat cultivars are given in Table 1 . Seeds were provided by Agricultural and Natural Resources Research Center of Isfahan Province, Iran.

\section{Experimental procedures}

The experiment was conducted in 2013 under greenhouse conditions at Isfahan University of Technology $\left(32^{\circ} 33^{\prime} \mathrm{N} ; 51^{\circ} 31^{\prime} 45^{\prime} \mathrm{E}, 1602 \mathrm{~m}\right.$ above sea level), Iran. For the purposes of this study, 20 Iranian bread wheat cultivars (Table 1) were grown under two different environments (ambient $\mathrm{CO}_{2}$ of $380 \pm 50 \mu \mathrm{mol} \mathrm{mol}^{-1}$ and enriched $\mathrm{CO}_{2}$ of $\left.700 \pm 50 \mu \mathrm{mol} \mathrm{mol}{ }^{-1}\right)$. The average air temperature throughout the experiment fluctuated between 25 and 32 ${ }^{\circ} \mathrm{C}$ and relative humidity ranged from 50 to $70 \%$.

For the $\mathrm{CO}_{2}$ treatments, two separate plastic containers, each $24 \mathrm{~m}^{3}$, were initially designed and prepared. One container was equipped with an automated $\mathrm{CO}_{2}$ gas injection system. The device was set at $700 \pm 50 \mathrm{~mol} \mathrm{~mol}^{-1}$ using interchangeable $\mathrm{CO}_{2}$ cylinders of $10 \mathrm{~kg}$. The other container was used as the control treatment and contained only ambient air $\mathrm{CO}_{2}$.

\section{Planting seeds and seedling growth}

Seeds of the selected wheat cultivars were first sterilized in a solution of $2 \%$ sodium hypochlorite for $2 \mathrm{~min}$, washed properly with water and planted in seedling trays filled with cocopeat. Wheat seedlings were kept under the same conditions up to the two-leaf stage before they were transplanted into the pores made on polystyrene layers floating on each pan. Seedling roots were completely placed in distilled water in the pan for three days when distilled water was replaced with the modified Hoagland nutrient solution to supply all the nutrients necessary for plant growth (Hoagland and Arnon, 1950).

After one week, the ventilation system was established for the solutions in the pans. During the study period, the acidity $(\mathrm{pH})$ and electrical conductivity $(\mathrm{EC})$ of the control treatment were set to 7.5 and $2.5 \mathrm{dS} / \mathrm{m}$, respectively. To avoid extensive changes in the composition of the nutrient solution, it was renewed once a week. The $\mathrm{CO}_{2}$ treatments were effected from the 3-leaf stage onwards.

Table 1. Main characteristics of the investigated Iranian bread wheat cultivars

\begin{tabular}{|c|c|c|c|c|c|c|}
\hline Cultivars & Growth type & Grain yield $\left(\mathrm{t} \mathrm{ha}^{-1}\right)$ & 1.000 seed weight $(\mathrm{g})$ & Height $(\mathrm{cm})$ & Year introduced & Planting areas \\
\hline 'Sistan' & $S$ & 4.32 & 48 & $90-95$ & 1991 & $\mathrm{Wd} \& \mathrm{~T}$ \\
\hline 'Bahar' & S & 6.67 & 38 & 95 & 2007 & $\mathrm{~T}$ \\
\hline 'Navid' & I & 5.0 & 41 & 108 & 1990 & $\mathrm{C}$ \\
\hline ‘Shiraz’ & S & 7.29 & 40 & 101 & 2002 & $\mathrm{~T}$ \\
\hline 'Shoeleh' & S & 3.00 & 43 & 115 & 1958 & $\mathrm{~T}$ \\
\hline 'Pishtaz' & S & 6.5 & 44 & 94 & 2002 & $\mathrm{~T}$ \\
\hline 'Kavir' & S & 4.14 & 38 & $85-90$ & 2006 & $\mathrm{Wd} \& \mathrm{~T}$ \\
\hline 'Sepahan' & S & 10.0 & 40 & $95-100$ & 2006 & $\mathrm{~T}$ \\
\hline 'Karaj' & W & 5.0 & 44.5 & 115 & 1973 & $\mathrm{C}$ \\
\hline 'Ghods' & I & 6.0 & 42 & 97.5 & 1989 & $\mathrm{~T}$ \\
\hline 'Gaspard' & W & 6.14 & 39 & $85-90$ & 1994 & $\mathrm{C}$ \\
\hline 'Chamran' & S & $5.5-6.5$ & 39 & $90-100$ & 1997 & $\mathrm{Wd} \& \mathrm{~T}$ \\
\hline 'Tajan' & S & 6.30 & 38 & $95-100$ & 1995 & $\mathrm{~T}$ \\
\hline 'Alamoot' & W & 6.40 & 36 & 100 & 1995 & $\mathrm{C}$ \\
\hline 'Khoshkill' & S & 5.00 & 35 & - & - & Wd \\
\hline 'Shahriyar' & W & 6.72 & 38 & 105 & 2002 & $\mathrm{C}$ \\
\hline 'Marun' & S & 3.04 & 39.5 & 94 & 1991 & Wd \\
\hline 'Sorkhtokhm’ & S & 3.50 & 25.5 & - & 1941 & Wd \\
\hline ‘Omid' & W & 6.8 & 40 & 110 & 1956 & C \\
\hline 'Marvdasht' & S & 6.7 & 36 & 102 & 1999 & $\mathrm{~T}$ \\
\hline
\end{tabular}


402

\section{Measurements}

After 35 days (mid-tillering stage), wheat seedlings were harvested and separated into roots and shoots. The green leaf area was measured using a digital leaf area meter (Model GA-5, OSK Company, Tokyo, Japan). Plant height was measured from crown to the extended tip of the newest fully developed leaf, using a metric ruler. Root volume was determined using the water displacement method (Pang et al., 2011). Plant root and shoot samples were oven dried at $70{ }^{\circ} \mathrm{C}$ for $48 \mathrm{~h}$ and their dry weights were separately recorded.

Nitrogen concentration of the shoot tissues was measured using the Berthelot reaction, in which a phenolic compound (salicylates) in the presence of ammonia and hypochlorite turns blue-green (Novozamsky et al., 1974). The absorption rate was measured by a spectrophotometer at a wavelength of $660 \mathrm{~nm}$.

The nitrogen content and nitrogen use efficiency (Cheng et al., 2011) were determined using the following formulas:

Nitrogen content $\left(\mathrm{g} \mathrm{plant}^{-1}\right)=$ Nitrogen concentration $\left(\mathrm{g} \mathrm{kg}^{-1}\right) \times$ dry weight $\left(\mathrm{kg} \mathrm{plant}^{-1}\right)$

Nitrogen User Efficiency (NUE) = Dry weight $(\mathrm{g}) /$ Nitrogen content $(\mathrm{g})$

Stress susceptibility index (SSI) (Fischer and Maurer, 1978) and stress tolerance index (STI) (Fernandez, 1992) were calculated as follows:

$$
\begin{aligned}
& \mathrm{SSI}=\left[1-\left(\mathrm{Y}_{\mathrm{si}} / \mathrm{Y}_{\mathrm{pi}}\right)\right] / \mathrm{SI} \\
& \mathrm{SI}=\left[1-\left(\mathrm{Y}_{\mathrm{S}} / \mathrm{Y}_{\mathrm{p}}\right)\right] \\
& \mathrm{STI}=\left(\mathrm{Y}_{\mathrm{si}} \times \mathrm{Y}_{\mathrm{pi}}\right) /\left(\mathrm{Yp}^{2}\right)
\end{aligned}
$$

where, $\mathrm{Ypi}=$ total dry biomass weight of individual cultivars in the absence of stress, Ysi = total dry biomass weight of individual cultivars in the presence of stress, Ys = average total dry biomass weight of all the cultivars in the presence of stress, and $\mathrm{Yp}=$ average total dry biomass weight of all the cultivars in the absence of stress. An elevated $\mathrm{CO}_{2}$ of $700 \pm 50 \mu \mathrm{mol} \mathrm{mol}{ }^{-1}$ was considered as a non-stress treatment and the ambient concentration of $\mathrm{CO}_{2}$ equal to $380 \pm 50 \mu \mathrm{mol} \mathrm{mol}{ }^{-1}$ was regarded as a stress treatment.

\section{Statistical analysis}

The Bartlett's test was initially conducted for homogeneity of error variances. The null hypothesis in terms of non-significant differences between the variances of the errors in the two environments (i.e., the ambient $\mathrm{CO}_{2}$ concentration of $380 \pm 50 \mathrm{umol} \mathrm{mol}^{-1}$ and the elevated one of $700 \pm 50 \mu \mathrm{mol} \mathrm{mol}^{-1}$ ) was not rejected.

Based on the uniformity of the error variances, the combined analysis of variances was performed as (20 wheat cultivars) experiment in a completely randomized design with three replications using SAS v9.1. The least significant difference (LSD) test was employed for mean comparisons at $\alpha$ level $=0.05$.

In addition, the Ward method was employed to identify cluster groups in dendrograms using the measured values of the different traits of the 20 Iranian bread wheat cultivars. Clustering was accomplished on the basis of changes (in \%) in the values of variables for the elevated (700) vs. ambient $\left(380 \mu \mathrm{mol} \mathrm{mol}^{-1}\right) \mathrm{CO}_{2}$ concentrations.

\section{Results}

Shoot nitrogen concentration, $N$ content and NUE

Shoot nitrogen concentration, nitrogen content and NUE were found to be significantly $(P<0.01)$ affected by elevated $\mathrm{CO}_{2}$ and cultivar (Table 2). The elevated vs. ambient $\mathrm{CO}_{2}$ decreased shoot nitrogen concentration by $10 \%$ on the average, but increased $\mathrm{N}$ content and NUE by 26 and 14\%, respectively. The highest and lowest mean shoot $\mathrm{N}$ concentrations of 108 and $3.40 \mathrm{mg} \mathrm{g}^{-1} \mathrm{DW}$ were observed in 'Alamoot' and 'Omid' as were the highest and lowest shoot $\mathrm{N}$ contents of 125 and $3.60 \mathrm{mg}$ shoot $^{-1}$. This is while the highest and lowest NUE values of 415 and 9.35 were measured for 'Omid' and 'Alamoot' cultivars, respectively (Table 2 ).

Finally, shoot NUE was significantly $(\mathrm{P}<0.01)$ affected by the interaction of $\mathrm{CO}_{2}$ and cultivar (Table 2). Under both elevated and ambient $\mathrm{CO}_{2}$, the highest and lowest NUE values belonged to 'Omid' and 'Alamoot' cultivars, respectively (Table 2 ).

\section{Chlorophyll a (Chl a), chlorophyll b (Chl b) and carotenoid concentrations}

Leaf Chla, Chlb and carotenoid concentrations were significantly $(\mathrm{P}<0.01)$ affected by elevated $\mathrm{CO}_{2}$ and wheat cultivar (Table 3). The elevated vs. ambient $\mathrm{CO}_{2}$ increased leaf Chla, Chlb and carotenoid concentrations by 25, 21, and $30 \%$, respectively (Table 3 ).

Leaf Chla, Chl $b$ and carotenoid concentrations were significantly $(\mathrm{P}<0.01)$ affected by the interaction of $\mathrm{CO}_{2}$ and wheat cultivar (Table 3). The highest and lowest mean Chla concentrations were observed in 'Alamoot' and 'Tajan', respectively, under both ambient (0.478 and 0.218$)$ and elevated $\left(0.508\right.$ and $\left.0.255 \mathrm{mg} \mathrm{g}^{-1} \mathrm{FW}\right) \mathrm{CO}_{2}$. Chl $b$ concentration recorded their highest and lowest values in 'Ghods' and 'Tajan' cultivars, respectively, under both ambient $(0.229$ and 0.139$)$ and elevated $(0.260$ and 0.180 $\left.\mathrm{mg} \mathrm{g}^{-1} \mathrm{FW}\right) \mathrm{CO}_{2}$. This is while 'Ghods' and 'Tajan' cultivars recorded the highest $\left(0.402 \mathrm{mg} \mathrm{g}^{-1} \mathrm{FW}\right)$ and lowest (0.300) mean values of carotenoid concentration under the ambient $\mathrm{CO}_{2}$ and 'Ghods' (0.495 $\left.\mathrm{mg} \mathrm{g}^{-1} \mathrm{FW}\right)$ and 'Marvdasht' (0.400 $\mathrm{mg} \mathrm{g}^{-1} \mathrm{FW}$ ) under the elevated $\mathrm{CO}_{2}$ (Table 3).

\section{Leaf area, plant height and root volume}

Leaf area, plant height and root volume were found to be significantly $(\mathrm{P}<0.01)$ affected by elevated $\mathrm{CO}_{2}$ and wheat cultivar (Tables 4 ). The elevated vs. ambient $\mathrm{CO}_{2}$ increased leaf area, plant height and root volume by 54, 49.4, and $51 \%$, respectively (Table 4). The highest and lowest mean values of 148 and $95 \mathrm{~cm}^{2}$ plant ${ }^{-1}$ were measured in 'Marun' and 'Omid', respectively, for leaf area; those of 63.1 and $42.6 \mathrm{~cm}$ were recorded in 'Marun' and 'Gaspard' cultivars for plant height and those of 15.7 and $10.1 \mathrm{~cm}^{3}$ in 'Navid' and 'Omid' cultivars, respectively, for root volume (Table 4). Interaction of $\mathrm{CO}_{2}$ and wheat cultivar also had significant $(\mathrm{P}<0.01)$ effects on leaf area, plant height and root volume (Table 4). The highest and lowest mean values of 133 and $72 \mathrm{~cm}^{2}$ plant ${ }^{-1}$ were observed for leaf area in 'Marun' and 'Navid', respectively, under the ambient $\mathrm{CO}_{2}$, while values of 198 and $113 \mathrm{~cm}^{2}$ plant ${ }^{-1}$ were recorded in 
'Navid' and 'Omid' cultivars under the elevated $\mathrm{CO}_{2}$ (Table 4). The values of 55.6 and $33.0 \mathrm{~cm}$ were obtained as the highest and lowest means in 'Marun' and 'Gaspard' for plant height under the ambient $\mathrm{CO}_{2}$. Under the elevated $\mathrm{CO}_{2}$, however, 'Marun' and 'Shahriyar' cultivars recorded the highest and lowest mean values of 69.7 and $50.7 \mathrm{~cm}$, respectively. Maximum $\left(13.4 \mathrm{~cm}^{3}\right.$ plant $\left.{ }^{-1}\right)$ and minimum $\left(7.8 \mathrm{~cm}^{3}\right.$ plant $\left.^{-1}\right)$ mean values of root volume belonged to 'Marun' and 'Tajan' cultivars under the ambient $\mathrm{CO}_{2}$ while the same values for the same trait were 20.8 and $11.1 \mathrm{~cm}^{3}$ plant ${ }^{-1}$ under the elevated $\mathrm{CO}_{2}$, which belonged to 'Navid' and 'Omid' cultivars, respectively (Table 4).

Finally, enhancements were observed in leaf area, plant height, and root volume in all the wheat cultivars examined as a result of increased $\mathrm{CO}_{2}$ although the extent of the enhancements varied with cultivar (Table 4). The highest and lowest increases were obtained as 175 and 23\% for leaf area in 'Navid' and 'Marun', 89 and 25\% for plant height in 'Sistan' and 'Marun', respectively, 96\% for root volume in 'Tajan' and 'Navid' and 7\% in 'Marvdasht' (Table 4).

Table 2. Effects of two $\left[\mathrm{CO}_{2}\right]\left(380 \pm 50\right.$ vs. $\left.700 \pm 50 \mu \mathrm{mol} \mathrm{mol}^{-1}\right)$ on nitrogen concentration $\left(\mathrm{mg} \mathrm{g}^{-1} \mathrm{DM}\right)$, nitrogen content $\left(\mathrm{mg} \mathrm{shoot}^{-1}\right)$ and NUE in the shoots of 20 Iranian bread wheat cultivars

\begin{tabular}{|c|c|c|c|c|c|c|c|c|c|c|c|c|}
\hline \multirow{3}{*}{ Cultivars } & \multicolumn{4}{|c|}{$\mathrm{N}$ concentration $\left(\mathrm{mg} \mathrm{g}^{-1} \mathrm{DM}\right)$} & \multicolumn{4}{|c|}{$\mathrm{N}$ content $\left(\mathrm{mg} \mathrm{shoot}^{-1}\right)$} & \multicolumn{4}{|c|}{ NUE } \\
\hline & \multicolumn{2}{|c|}{$\left[\mathrm{CO}_{2}\right]\left(\mu \mathrm{mol} \mathrm{mol}^{-1}\right)$} & \multirow{2}{*}{$\%$} & \multirow{2}{*}{ Mean } & \multicolumn{2}{|c|}{$\left[\mathrm{CO}_{2}\right]\left(\mu \mathrm{mol} \mathrm{mol}^{-1}\right)$} & \multirow{2}{*}{$\%$} & \multirow{2}{*}{ Mean } & \multicolumn{2}{|c|}{$\left[\mathrm{CO}_{2}\right]\left(\mu \mathrm{mol} \mathrm{mol}^{-1}\right)$} & \multirow{2}{*}{$\%$} & \multirow{2}{*}{ Mean } \\
\hline & 380 & 700 & & & 380 & 700 & & & 380 & 700 & & \\
\hline 'Sistan' & 17 & 15.5 & -9 & 16.3 & 13.6 & 24.6 & 81 & 19.1 & 58.8 & 64.6 & 10 & 61.7 \\
\hline 'Bahar' & 12 & 9.7 & -19 & 10.9 & 12.5 & 15.8 & 26 & 14.2 & 83.2 & 103 & 24 & 93.2 \\
\hline 'Navid' & 52.5 & 46.7 & -11 & 49.6 & 51.5 & 89.2 & 73 & 70.4 & 19.0 & 21.4 & 13 & 20.2 \\
\hline 'Shiraz' & 23.3 & 21.5 & -8 & 22.4 & 19.6 & 31.6 & 61 & 25.6 & 42.9 & 46.5 & 9 & 44.7 \\
\hline 'Shoeleh' & 14.8 & 10.1 & -32 & 12.5 & 13.6 & 14.4 & 6 & 14.0 & 67.6 & 99.3 & 47 & 83.5 \\
\hline 'Pishtaz' & 66.7 & 67.5 & 1 & 67.1 & 62.7 & 90.5 & 44 & 76.6 & 15.0 & 14.8 & -1 & 14.9 \\
\hline 'Kavir' & 96.7 & 101 & 4 & 98.9 & 84.1 & 116 & 38 & 100 & 10.3 & 9.9 & -4 & 10.1 \\
\hline 'Sepahan' & 77.5 & 75 & -3 & 76.3 & 59.7 & 94.5 & 58 & 77.1 & 12.9 & 13.3 & 3 & 13.1 \\
\hline 'Karaj' & 12.9 & 18.1 & 40 & 15.5 & 12.9 & 26.6 & 106 & 19.8 & 77.5 & 55.3 & -29 & 66.4 \\
\hline 'Ghods' & 88.3 & 84.2 & -5 & 86.3 & 79.5 & 108 & 36 & 93.8 & 11.3 & 11.9 & 6 & 11.6 \\
\hline 'Gaspard' & 8.2 & 5.8 & -29 & 7.0 & 6.6 & 7.0 & 6 & 6.80 & 121 & 173 & 43 & 147 \\
\hline 'Chamran' & 32.5 & 24.7 & -24 & 28.6 & 38.7 & 35.1 & -9 & 36.9 & 30.7 & 40.5 & 32 & 35.6 \\
\hline ‘Tajan' & 35.8 & 33.3 & -7 & 34.6 & 39.0 & 40.6 & 4 & 39.8 & 27.9 & 30.0 & 8 & 29.0 \\
\hline 'Alamoot' & 107 & 108 & 1 & 107 & 116 & 133 & 15 & 125 & 9.3 & 9.2 & -1 & 9.3 \\
\hline 'Khoshki11' & 47.5 & 45.8 & -4 & 46.7 & 51.3 & 57.7 & 12 & 54.5 & 21.1 & 21.8 & 4 & 21.4 \\
\hline 'Shahriyar' & 5.6 & 4.4 & -21 & 5.0 & 4.9 & 4.80 & -2 & 4.85 & 180 & 225 & 25 & 202 \\
\hline 'Marun' & 4.3 & 3.3 & -23 & 3.8 & 6.1 & 5.10 & -16 & 5.60 & 233 & 306 & 31 & 269 \\
\hline 'Sorkhtokhm' & 39.2 & 35 & -11 & 37.1 & 46.6 & 46.6 & 0 & 46.6 & 25.5 & 28.5 & 12 & 27.0 \\
\hline 'Omid' & 4.1 & 2.7 & -34 & 3.4 & 4.00 & 2.70 & -33 & 3.4 & 245 & 374 & 53 & 310 \\
\hline 'Marvdasht' & 104 & 95.8 & -8 & 99.9 & 114 & 120 & 5 & 117 & 9.6 & 10.4 & 8 & 10.0 \\
\hline Mean & $42.5^{a^{*}}$ & $40.4^{\mathrm{b}}$ & -10 & 41.5 & $41.8^{\mathrm{b}}$ & $53.2^{a}$ & 26 & 47.5 & $65.1^{2}$ & $82.9^{b}$ & 14 & 74.0 \\
\hline LSD $5 \%$ & \multicolumn{4}{|c|}{0.13} & \multicolumn{4}{|c|}{0.10} & \multicolumn{4}{|c|}{3.80} \\
\hline \multicolumn{13}{|c|}{ Source of variation } \\
\hline$\left[\mathrm{CO}_{2}\right]$ & \multicolumn{4}{|c|}{$<0.01$} & \multicolumn{4}{|c|}{$<0.01$} & \multicolumn{4}{|c|}{$<0.01$} \\
\hline Cultivar (C) & \multicolumn{4}{|c|}{$<0.01$} & \multicolumn{4}{|c|}{$<0.01$} & \multicolumn{4}{|c|}{$<0.01$} \\
\hline$\left[\mathrm{CO}_{2}\right]^{*} \mathrm{C}$ & \multicolumn{4}{|c|}{$<0.01$} & \multicolumn{4}{|c|}{$<0.01$} & \multicolumn{4}{|c|}{$<0.01$} \\
\hline
\end{tabular}

Table 3. Effects of two $\left[\mathrm{CO}_{2}\right]\left(380 \pm 50\right.$ vs. $\left.700 \pm 50 \mu \mathrm{mol} \mathrm{mol}^{-1}\right)$ on chlorophyll a $\left(\mathrm{mg} \mathrm{g}^{-1} \mathrm{FW}\right)$, chlorophyll b $\left(\mathrm{mg} \mathrm{g}^{-1} \mathrm{FW}\right)$ and carotenoid concentrations $\left(\mathrm{mg} \mathrm{g}^{-1} \mathrm{FW}\right)$ in the leaves of 20 Iranian bread wheat cultivars

\begin{tabular}{|c|c|c|c|c|c|c|c|c|c|c|c|c|}
\hline \multirow{3}{*}{ Cultivars } & \multicolumn{4}{|c|}{ Chlorophyll $a\left(\mathrm{mgg}^{-1} \mathrm{FW}\right)$} & \multicolumn{4}{|c|}{ Chlorophyll $b\left(\mathrm{mg} \mathrm{g}^{-1} \mathrm{FW}\right)$} & \multicolumn{4}{|c|}{ Carotenoid $\left(\mathrm{mg} \mathrm{g}^{-1} \mathrm{FW}\right)$} \\
\hline & \multicolumn{2}{|c|}{$\left[\mathrm{CO}_{2}\right]\left(\mu \mathrm{mol} \mathrm{mol}^{-1}\right)$} & \multirow{2}{*}{$\%$} & \multirow{2}{*}{ Mean } & \multicolumn{2}{|c|}{$\left[\mathrm{CO}_{2}\right]\left(\mu \mathrm{mol} \mathrm{mol}^{-1}\right)$} & \multirow{2}{*}{$\%$} & \multirow{2}{*}{ Mean } & \multicolumn{2}{|c|}{$\left[\mathrm{CO}_{2}\right]\left(\mu \mathrm{mol} \mathrm{mol}^{-1}\right)$} & \multirow{2}{*}{$\%$} & \multirow{2}{*}{ Mear } \\
\hline & 380 & 700 & & & 380 & 700 & & & 380 & 700 & & \\
\hline 'Sistan' & 0.288 & 0.442 & 53 & 0.365 & 0.172 & 0.237 & 38 & 0.205 & 0.345 & 0.448 & 30 & 0.397 \\
\hline 'Bahar' & 0.372 & 0.452 & 22 & 0.412 & 0.173 & 0.195 & 13 & 0.184 & 0.330 & 0.432 & 31 & 0.381 \\
\hline 'Navid' & 0.343 & 0.442 & 29 & 0.393 & 0.205 & 0.240 & 17 & 0.223 & 0.348 & 0.482 & 39 & 0.415 \\
\hline 'Shiraz' & 0.274 & 0.342 & 25 & 0.308 & 0.213 & 0.222 & 4 & 0.218 & 0.327 & 0.490 & 50 & 0.409 \\
\hline 'Shoeleh' & 0.253 & 0.343 & 36 & 0.298 & 0.173 & 0.207 & 20 & 0.190 & 0.332 & 0.437 & 32 & 0.385 \\
\hline 'Pishtaz' & 0.270 & 0.297 & 10 & 0.284 & 0.173 & 0.228 & 32 & 0.201 & 0.330 & 0.457 & 38 & 0.394 \\
\hline
\end{tabular}




\begin{tabular}{|c|c|c|c|c|c|c|c|c|c|c|c|c|}
\hline 'Kavir' & 0270 & 0385 & 43 & 0328 & 0158 & 0205 & 30 & 0187 & 0320 & 0427 & 33 & 0374 \\
\hline 'Sepahan' & 0.318 & 0.362 & 14 & 0.340 & 0.163 & 0.198 & 21 & 0.181 & 0.330 & 0.415 & 26 & 0.373 \\
\hline 'Karaj' & 0.244 & 0.382 & 57 & 0.313 & 0.150 & 0.208 & 39 & 0.179 & 0.320 & 0.418 & 31 & 0.369 \\
\hline 'Ghods' & 0.414 & 0.458 & 11 & 0.436 & 0.229 & 0.260 & 14 & 0.245 & 0.402 & 0.495 & 23 & 0.449 \\
\hline 'Gaspard’ & 0.234 & 0.284 & 21 & 0.259 & 0.160 & 0.193 & 21 & 0.177 & 0.313 & 0.425 & 36 & 0.369 \\
\hline 'Chamran' & 0.358 & 0.396 & 11 & 0.377 & 0.177 & 0.233 & 32 & 0.205 & 0.360 & 0.445 & 24 & 0.403 \\
\hline ‘Tajan' & 0.218 & 0.255 & 17 & 0.237 & 0.139 & 0.180 & 29 & 0.160 & 0.300 & 0.410 & 37 & 0.355 \\
\hline 'Alamoot' & 0.478 & 0.508 & 6 & 0.493 & 0.218 & 0.233 & 7 & 0.226 & 0.378 & 0.457 & 21 & 0.418 \\
\hline 'Khoshkill' & 0.344 & 0.430 & 25 & 0.387 & 0.203 & 0.228 & 12 & 0.216 & 0.348 & 0.472 & 36 & 0.410 \\
\hline 'Shahriyar' & 0.400 & 0.500 & 25 & 0.450 & 0.187 & 0.242 & 29 & 0.215 & 0.372 & 0.442 & 19 & 0.407 \\
\hline 'Marun' & 0.301 & 0.408 & 36 & 0.355 & 0.196 & 0.235 & 20 & 0.216 & 0.368 & 0.442 & 20 & 0.405 \\
\hline 'Sorkhtokhm' & 0.275 & 0.302 & 10 & 0.289 & 0.193 & 0.210 & 9 & 0.202 & 0.343 & 0.438 & 28 & 0.391 \\
\hline 'Omid' & 0.333 & 0.456 & 37 & 0.395 & 0.168 & 0.233 & 39 & 0.201 & 0.335 & 0.452 & 35 & 0.394 \\
\hline 'Marvdasht' & 0.310 & 0.373 & 20 & 0.342 & 0.187 & 0.199 & 6 & 0.193 & 0.353 & 0.400 & 13 & 0.377 \\
\hline Mean & $0.315^{\mathrm{b} *}$ & $0.391^{2}$ & 25 & & $0.182^{b}$ & $0.219^{2}$ & 21 & & $0.343^{\mathrm{b}}$ & $0.444^{2}$ & 30 & \\
\hline LSD $5 \%$ & \multicolumn{4}{|c|}{0.019} & \multicolumn{4}{|c|}{0.01} & \multicolumn{4}{|c|}{0.02} \\
\hline \multicolumn{13}{|c|}{ Source of variation } \\
\hline$\left[\mathrm{CO}_{2}\right]$ & \multicolumn{4}{|c|}{$<0.01$} & \multicolumn{4}{|c|}{$<0.01$} & \multicolumn{4}{|c|}{$<0.01$} \\
\hline Cultivar (C) & \multicolumn{4}{|c|}{$<0.01$} & \multicolumn{4}{|c|}{$<0.01$} & \multicolumn{4}{|c|}{$<0.01$} \\
\hline$\left[\mathrm{CO}_{2}\right]^{*} \mathrm{C}$ & \multicolumn{4}{|c|}{$<0.01$} & \multicolumn{4}{|c|}{$<0.01$} & \multicolumn{4}{|c|}{$<0.01$} \\
\hline
\end{tabular}

Table 4. Effects of two $\left[\mathrm{CO}_{2}\right]\left(380 \pm 50\right.$ vs. $\left.700 \pm 50 \mu \mathrm{mol} \mathrm{mol}{ }^{-1}\right)$ on leaf area $\left(\mathrm{cm}^{2}\right.$ plant $\left.{ }^{-1}\right)$, plant height $(\mathrm{cm})$ and root volume $\left(\mathrm{cm}^{3}\right.$ plant $\left.{ }^{-1}\right)$ of 20 Iranian bread wheat cultivars

\begin{tabular}{|c|c|c|c|c|c|c|c|c|c|c|c|c|}
\hline \multirow{4}{*}{ Cultivars } & \multicolumn{4}{|c|}{ Leaf area $\left(\mathrm{cm}^{2}\right.$ plant $\left.{ }^{-1}\right)$} & \multicolumn{4}{|c|}{ Plant height $(\mathrm{cm})$} & \multicolumn{4}{|c|}{ Root volume $\left(\mathrm{cm}^{3}\right.$ plant $\left.{ }^{-1}\right)$} \\
\hline & \multicolumn{2}{|c|}{$\left[\mathrm{CO}_{2}\right]$} & \multirow{3}{*}{$\%$} & \multirow{3}{*}{ Mean } & \multirow{2}{*}{\multicolumn{2}{|c|}{$\left[\mathrm{CO}_{2}\right]$}} & \multirow{3}{*}{$\%$} & \multirow{3}{*}{ Mean } & \multirow{2}{*}{\multicolumn{2}{|c|}{$\begin{array}{c}{\left[\mathrm{CO}_{2}\right]} \\
\left(\mu \mathrm{mol} \mathrm{mol}^{-1}\right)\end{array}$}} & \multirow{3}{*}{$\%$} & \multirow{3}{*}{ Mean } \\
\hline & \multicolumn{2}{|c|}{$\left(\mu \mathrm{mol} \mathrm{mol}{ }^{-1}\right)$} & & & & & & & & & & \\
\hline & 380 & 700 & & & 380 & 700 & & & 380 & 700 & & \\
\hline 'Sistan' & 88 & 166 & 89 & 127 & 35.2 & 66.5 & 88.9 & 50.9 & 8.4 & 13.8 & 65 & 11.08 \\
\hline 'Bahar' & 110 & 175 & 59 & 143 & 45.5 & 63.2 & 38.9 & 54.4 & 9.6 & 13.9 & 45 & 11.74 \\
\hline 'Navid' & 72 & 198 & 175 & 135 & 42.4 & 65.7 & 55.0 & 54.1 & 10.6 & 20.8 & 96 & 15.70 \\
\hline 'Shiraz' & 87 & 151 & 74 & 119 & 36.5 & 62.5 & 71.2 & 49.5 & 9.9 & 17.8 & 79 & 13.86 \\
\hline 'Shoeleh' & 96 & 154 & 60 & 125 & 37.8 & 57.7 & 52.6 & 47.8 & 10.7 & 15.2 & 42 & 12.95 \\
\hline 'Pishtaz' & 101 & 145 & 44 & 123 & 38.8 & 55.0 & 41.8 & 46.9 & 10.3 & 16.7 & 62 & 13.50 \\
\hline 'Kavir' & 94 & 144 & 53 & 119 & 35.5 & 55.7 & 56.9 & 45.6 & 10.3 & 16.9 & 64 & 13.60 \\
\hline 'Sepahan' & 94 & 133 & 41 & 114 & 36.3 & 52.8 & 45.5 & 44.6 & 10.7 & 14.4 & 35 & 12.55 \\
\hline 'Karaj' & 106 & 155 & 46 & 131 & 41.7 & 61.0 & 46.3 & 51.4 & 11.5 & 17.8 & 55 & 14.65 \\
\hline 'Ghods' & 95 & 138 & 45 & 117 & 37.3 & 54.8 & 46.9 & 46.1 & 10.2 & 16.7 & 64 & 13.45 \\
\hline 'Gaspard' & 87 & 129 & 48 & 108 & 32.7 & 52.5 & 60.6 & 42.6 & 8.3 & 14.6 & 77 & 11.43 \\
\hline 'Chamran' & 113 & 152 & 35 & 133 & 46.0 & 61.8 & 34.3 & 53.9 & 10.2 & 14.6 & 43 & 12.40 \\
\hline 'Tajan' & 85 & 133 & 56 & 109 & 33.0 & 56.3 & 70.6 & 44.7 & 7.8 & 15.2 & 96 & 11.48 \\
\hline 'Alamoot' & 99 & 142 & 43 & 121 & 39.7 & 61.0 & 53.7 & 50.4 & 10.8 & 15.9 & 47 & 13.35 \\
\hline 'Khoshkill' & 104 & 146 & 40 & 125 & 41.3 & 60.0 & 45.3 & 50.7 & 13.0 & 16.0 & 23 & 14.50 \\
\hline 'Shahriyar' & 84 & 119 & 42 & 102 & 35.8 & 50.7 & 41.6 & 43.3 & 10.5 & 14.0 & 33 & 12.25 \\
\hline 'Marun' & 133 & 164 & 23 & 149 & 55.6 & 69.7 & 25.4 & 62.7 & 13.4 & 17.0 & 27 & 15.20 \\
\hline 'Sorkhtokhm' & 105 & 148 & 41 & 127 & 45.8 & 62.8 & 37.1 & 54.3 & 12.3 & 17.0 & 38 & 14.65 \\
\hline ‘Omid' & 78 & 113 & 45 & 96 & 36.5 & 53.5 & 46.6 & 45.0 & 9.1 & 11.1 & 22 & 10.09 \\
\hline 'Marvdasht' & 107 & 136 & 27 & 122 & 46.3 & 59.7 & 28.9 & 53.0 & 12.4 & 13.3 & 7 & 12.85 \\
\hline Mean & $96.9^{6^{*}}$ & $147^{\mathrm{a}}$ & 54 & & $39.5^{\mathrm{b}}$ & $59.1^{2}$ & 49.4 & & $10.5^{\mathrm{b}}$ & $15.6^{a}$ & 51.2 & \\
\hline LSD 5\% & & 4. & & & & & & & & 1. & & \\
\hline & Sourc & riation & & & & & & & & & & \\
\hline$\left[\mathrm{CO}_{2}\right]$ & & $<0$ & & & & & & & & $<0$ & & \\
\hline Cultivar (C) & & $<0$ & & & & & & & & $<0$ & & \\
\hline$\left[\mathrm{CO}_{2}\right]{ }^{*} \mathrm{C}$ & & $<0$ & & & & & & & & $<0$ & & \\
\hline
\end{tabular}


Shoot, root and shoot/ root dry weight $(S / R)$ ratio

Shoot and root dry weights were both significantly $(\mathrm{P}<$ 0.01 ) affected by the elevated $\mathrm{CO}_{2}$ treatment and cultivar (Table 5$)$. The $S / R$ ratio was also significantly $(\mathrm{P}<0.01)$ affected by cultivar (Table 5$)$. Shoot and root dry weights exhibited increases of $39 \%$ and $18 \%$ in the elevated $\mathrm{CO}_{2}$ treatment (Table 5). The highest and lowest values of shoot dry weight were obtained to be 1.49 and 0.98 g plant $^{-1}$ for 'Marun' and 'Shahriyar'; root dry weight were 0.255 in 'Marun' and $0.17 \mathrm{~g}$ plant $^{-1}$ in 'Omid', 'Gaspard' and 'Shoeleh'; S/R ratio were 8.07 and 5.38 in the 'Sistan' and 'Shahriyar' cultivars, respectively (Table 5).

Interaction of $\mathrm{CO}_{2}$ and cultivar had significant $(\mathrm{P}<$ 0.01 ) effects on shoot and root dry weights, as well as $S / R$ ratio (Table 5). The highest and lowest values of shoot dry weight were determined to be 1.42 and $0.770 \mathrm{~g} \mathrm{plant}^{-1}$ in 'Marun' and 'Sepahan', respectively, under the ambient $\mathrm{CO}_{2}$, but 1.91 and $1.01 \mathrm{~g}^{-1}$ plant $^{-1}$ in 'Navid' and 'Omid' under the elevated $\mathrm{CO}_{2}$, respectively (Table S5). Root dry weight recorded the highest and lowest values of 0.250 and 0.150 g plant $^{-1}$ in 'Marun' and 'Omid-Gaspard', respectively, under the ambient $\mathrm{CO}_{2}$, but under the elevated $\mathrm{CO}_{2}$ 'Sistan' recorded the highest root dry weight of 0.270 , while 'Omid' and 'Shoeleh' recorded the lowest value of $0.180 \mathrm{~g}$ plant $^{-1}$. S/R ratio recorded its highest value of 6.53 in 'Omid' and its lowest value of 4.53 in 'Sepahan' under the ambient $\mathrm{CO}_{2}$. Values of 9.10 and 5.14 were recorded for this same trait in 'Navid' and 'Shahriyar' cultivars, respectively, under the elevated $\mathrm{CO}_{2}$ treatment (Table 5).

All the investigated wheat cultivars exhibited enhanced shoot and root dry weights in the elevated $\mathrm{CO}_{2}$ treatment; the enhancements, however, varied with cultivar such that the highest and lowest increases of 99\% and 3\% were observed in 'Sistan' and 'Omid', respectively, for shoot dry weight. Root dry weight had its highest increase of $69 \%$ in 'Sistan' and its lowest increase of 4\% in 'Marun'. S/R ratio decreased in some cultivars but increased in others under the elevated $\mathrm{CO}_{2}$ treatment. The highest and lowest decreases of $14 \%$ and $0 \%$ belonged to 'Omid' and 'Tajan', respectively, while the highest and lowest increases of $86 \%$ and $4 \%$ were recorded for 'Navid' (Table 5 ).

\section{Discussion}

The current atmospheric carbon dioxide concentration of $400 \mu \mathrm{mol} \mathrm{mol}^{-1}$ is considered as a limiting factor to photosynthesis rate in $\mathrm{C}_{3}$ plants. Increased $\mathrm{CO}_{2}$ concentration can, therefore, improve photosynthesis primarily due to the associated enhancement in Rubisco carboxylation capacity (Long et al., 2004; Kant et al., 2012), which, in turn, reduces $\mathrm{CO}_{2}$ losses to photorespiration (Barnaby and Ziska, 2012).

Table 5. Effects of two $\left[\mathrm{CO}_{2}\right]\left(380 \pm 50 \mathrm{vs.} 700 \pm 50 \mu \mathrm{mol} \mathrm{mol}^{-1}\right)$ on shoot $\left(\mathrm{g} \mathrm{plant}^{-1}\right)$, root $\left(\mathrm{g} \mathrm{plant}^{-1}\right)$ and shoot/ root dry weight ratio of 20 Iranian bread wheat cultivars

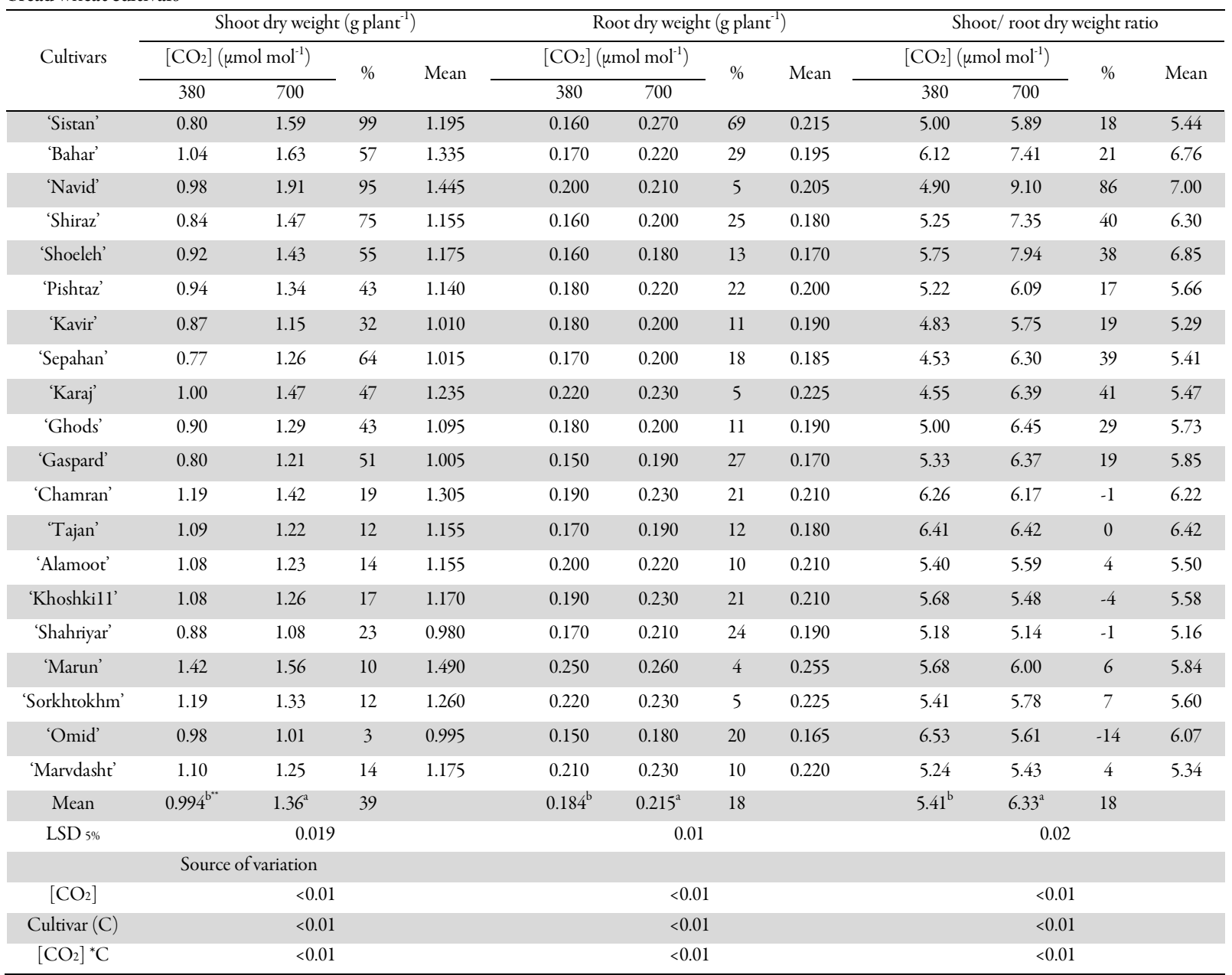


406

Table 6. Average values of SSI and STI in Iranian bread wheat cultivars. The values are based on total dry biomass (shoot plus root dry weights)

\begin{tabular}{|c|c|c|}
\hline \multirow{2}{*}{ Cultivar } & \multicolumn{2}{|c|}{$\mathrm{CO}_{2}$} \\
\hline & SSI & STI \\
\hline 'Sistan' & 1.93 & 0.72 \\
\hline 'Bahar' & 1.38 & 0.91 \\
\hline 'Navid' & 1.77 & 1.01 \\
\hline 'Shiraz' & 1.60 & 0.68 \\
\hline 'Shoeleh' & 1.32 & 0.70 \\
\hline 'Pishtaz' & 1.13 & 0.71 \\
\hline 'Kavir' & 0.89 & 0.57 \\
\hline 'Sepahan' & 1.42 & 0.56 \\
\hline 'Karaj' & 1.13 & 0.84 \\
\hline 'Ghods' & 1.10 & 0.65 \\
\hline 'Gaspard' & 1.28 & 0.54 \\
\hline 'Chamran’ & 0.65 & 0.92 \\
\hline 'Tajan' & 0.43 & 0.72 \\
\hline 'Alamoot' & 0.47 & 0.75 \\
\hline 'Khoshkill' & 0.59 & 0.77 \\
\hline 'Shahriyar' & 0.74 & 0.55 \\
\hline 'Marun' & 0.33 & 1.23 \\
\hline 'Sorkhtokhm' & 0.38 & 0.89 \\
\hline 'Omid' & 0.20 & 0.55 \\
\hline 'Marvdasht' & 0.46 & 0.79 \\
\hline
\end{tabular}

*The elevated $\left[\mathrm{CO}_{2}\right]$ of $700 \pm 50 \mu \mathrm{mol} \mathrm{mol}{ }^{-1}$ serves as the non-stress treatment while the ambient $\mathrm{CO}_{2}$ of $380 \pm 50 \mu \mathrm{mol} \mathrm{mol}^{-1}$ serves as the stress treatment.

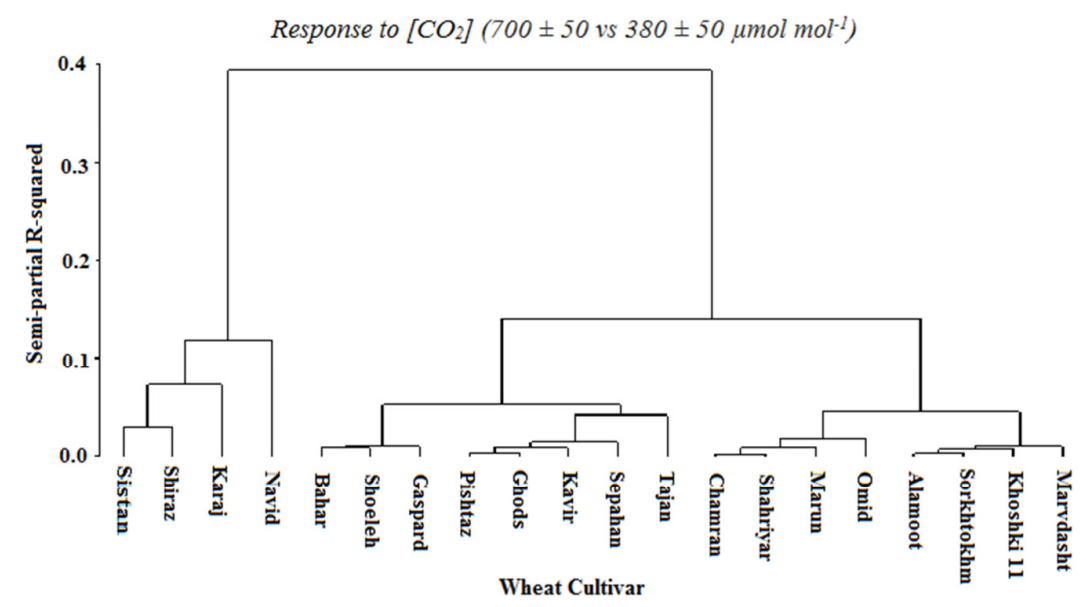

Fig. 1. Hierarchical cluster analysis: Dendrogram using the Ward Method and the variables consisting of nitrogen concentration, nitrogen content, NUE, leaf area, plant height, root volume, chlorophyll $a$, chlorophyll $b$, carotenoid concentration, shoot dry weight, root dry weight and shoot/ root dry weight $(\mathrm{S} / \mathrm{R})$ ratio in 20 Iranian bread wheat cultivars. Based on changes (\%) in the measured values of the variables for an elevated $\left[\mathrm{CO}_{2}\right]$ concentration of $700 \mathrm{vs}$ the ambient concentration of $380 \mu \mathrm{mol} \mathrm{mol}^{-1}$

The current results indicated that under elevated $\mathrm{CO}_{2}$ ( $\sim 700$ vs. $\left.\sim 380 \mu \mathrm{mol} \mathrm{mol}^{-1}\right)$, root and shoot dry weights experienced average enhancements of $36 \%$ and $17 \%$, respectively in Iranian wheat cultivars. This was associated with enhanced chlorophyll $a(25 \%)$, chlorophyll $b(21 \%)$, carotenoid (30\%), leaf area (54\%) and height (49.9\%) in the plants grown under a $\mathrm{CO}_{2}$ enriched atmosphere (Tables 3 and 4). This suggests that leaf area had a comparatively greater contribution to the positive response of wheat cultivars to elevated $\mathrm{CO}_{2}$ (Table 3 ). These findings are also supported by those reported by other researchers. Van der Kooi $e t$ al. (2016) stated that both biomass and yield of $\mathrm{C}_{3}$ crops have steadily increased when grown under elevated
$\mathrm{CO}_{2}$. Ainsworth and Rogers (2007) reported an average increase of $40 \%$ in photosynthetic rate in a variety of plant species grown under elevated $\mathrm{CO}_{2}$ in the range of $475-600$ umol mol ${ }^{-1}$. Cai $e t$ al. (2016) examined the influence of elevated $\mathrm{CO}_{2}$ concentrations ( $\sim 50$ vs. $\sim 370 \mu \mathrm{mol} \mathrm{mol}^{-1}$ ) in semi-arid environments and concluded that average yield stimulation was 24\% in 'Horsham' and 53\% in 'Walpeup'. Madhu and Hatfield (2014) reported that roots become more abundant, longer, thicker and faster growing when crops are grown under high $\mathrm{CO}_{2}$ conditions. Other studies reported that elevated $\mathrm{CO}_{2}$ could lead to faster development of the root system in winter wheat (Triticum aestivum L.) (Chaudhuri et al., 1990) or higher root weight 
in sorghum (Sorghum bicolor L. Moench) (Chaudhuri et al., 1986), improved root length, surface area, volume and tip numbers in two Lolium species (Jia et al., 2011) and increased root length (110\%) and root dry weight (143\%) in soybean (Rogers et al., 1992).

Compared to the ambient $\mathrm{CO}_{2}$, however, elevated levels led to reduced shoot $\mathrm{N}$ concentration by an average value of $10 \%$ in the different studied wheat cultivars. This is while previous studies reported a range of 10-15\% (Ainsworth and Long, 2005; Seneweera, 2010). The reduced N concentration could be attributed to such factors as nitrogen dilution in plant tissue, lower transpirational $\mathrm{N}$ flow as a result of reduced stomatal conductance, reduced $\mathrm{N}$ uptake due to soil-root source effects, reduced $\mathrm{N}$ demand due to the down-regulation of photosynthetic enzymes, reduced $\mathrm{N}$ assimilation capacity and declining electron flows for nitrate (Taub and Wang, 2008; Kant et al., 2012).

The effect of increased carbon dioxide on NUE was observed to vary with cultivar (Table 2). Under elevated $\mathrm{CO}_{2}, \mathrm{NUE}$ was increased from $4 \%$ to $53 \%$ in most of the investigated cultivars; however, cv. 'Karaj' exhibited a significant decrease in this trait (Table 2). Elevated $\mathrm{CO}_{2}$ $\left(\sim 550\right.$ vs $\left.\sim 330 \quad \mu \mathrm{mol} \quad \mathrm{mol}^{-1}\right)$ reportedly increased photosynthesis at all canopy levels and enhanced nitrogen use efficiency in the spring wheat plants under FACE plots (Arp, 1991). It has also been shown that elevated $\mathrm{CO}_{2}$ concentrations (700 and $350 \mu \mathrm{mol} \mathrm{mol}^{-1}$ ) enhance both $\mathrm{N}$ and agronomic $\mathrm{N}$ use efficiencies in the spring wheat, and that this effect is more pronounced under lower, rather than high, levels of $\mathrm{N}$ application (Li et al., 2003). However, the reduced plant wheat biomass under an enriched $\mathrm{CO}_{2}$ atmosphere observed in some experiments might imply a decrease in $\mathrm{N}$ use efficiency.

Plant growth response, as realized by the different traits measured, to elevate $\mathrm{CO}_{2}$ was found to depend on cultivar (Tables 2-5). With increasing $\mathrm{CO}_{2}$ concentration, changes were observed from -34 to $40 \%$ in $\mathrm{N}$ concentration, from -33 to $106 \%$ in N content, from -29 to $53 \%$ in NUE (Table 2), from 23 to $175 \%$ in leaf area, from 25.4 to $88.9 \%$ in plant height, from 7 to $96 \%$ in root volume (Table 3), from 6 to $57 \%$ in Chla, from 4 to $39 \%$ in Chlb, from 13 to $50 \%$ in carotenoid (Table 4), from 3\% to $99 \%$ in shoot dry weight, from $4 \%$ to $69 \%$ in root dry weight and from -14 to $80 \%$ in shoot/root dry weight ratio. Cluster analysis, which separates genotypes into groups exhibiting a high homogeneity within each group and heterogeneity across the classified groups (Jaynes et al., 2003) was used to classify the cultivars into two major clusters according to the percentage changes of the measured traits in response to the elevated $\mathrm{CO}_{2}$ concentration. Cluster I consist of 4 cultivars, while cluster II includes 16 that are further divided into two sub-clusters each consisting of 8 wheat cultivars (Fig. 1).

The development of crop varieties that enjoy a high potential for fixing $\mathrm{CO}_{2}$ in their photosynthetic process is considered as an appropriate solution in the face of rising atmospheric $\mathrm{CO}_{2}$ and achieving food security (Kant $e t$ al., 2012). The present findings of the experiment showed significant variation among the Iranian wheat cultivars in terms of their response to elevated air $\mathrm{CO}_{2}$, providing the opportunity to select the most efficient ones for breeding purposes.
Based on the SSI and STI indices, that are probably used for the first time to identify the response of wheat cultivars to the increase of carbon dioxide, the wheat cultivars exhibiting the best response to elevated $\mathrm{CO}_{2}$ content were 'Sistan', 'Navid', 'Shiraz', 'Sepahan' and 'Bahar', while the ones with poor responses were 'Omid', 'Marun', 'Sorkhtokhm' and 'Tajan' (Table 6). This is confirmed by other studies (Musgrave and Strain, 1988; Amthor, 2001; Bourgault et al., 2013) that have disclosed the capacity of wheat germplasm for enhanced adaptability to elevated $\mathrm{CO}_{2}$ content. Barnaby and Ziska (2012) found that plants exhibit both inter- and intra-species differences in their molecular, genetic and physiological responses to rising air $\mathrm{CO}_{2}$. Manderscheid and Weigel (1997) also reported of spring wheat cultivars, introduced between 1890 and 1988, that differed in their response to atmospheric $\mathrm{CO}_{2}$ enrichments of as high as $689 \mu \mathrm{mol} \mathrm{mol}^{-1}$. They found that the differences were mostly due to differences in tillering rate, spike number and grain number per spike, especially in old cultivars as compared to modern ones.

It has been claimed that the variation among wheat cultivars in response to elevated $\mathrm{CO}_{2}$ could be explained by differences in net photosynthesis $\left(\mathrm{P}_{\mathrm{N}}\right)$, stomatal conductance (gs), transpiration (E) and water use efficiency (WUE), as well as their antioxidant enzyme systems (Bencze et al., 2014). In the present experiment, leaf area ( $\mathrm{r}$ $\left.=0.69^{*}\right)$, shoot $\mathrm{N}$ content $\left(\mathrm{r}=0.62^{\circ}\right)$, plant height $(\mathrm{r}=$ $\left.0.60^{*}\right)$ and root volume $\left(\mathrm{r}=0.53^{\circ}\right)$ were found to have important roles in dry matter accumulation in wheat cultivars under elevated $\mathrm{CO}_{2}$ concentrations.

\section{Conclusions}

The investigated Iranian bread wheat cultivars in the present experiment exhibited large variations in their response to the atmospheric $\mathrm{CO}_{2}$, suggesting that the cultivars enjoy the considerable genetic capacity for yield improvements under elevated $\mathrm{CO}_{2}$ concentration. In addition, under increasing $\mathrm{CO}_{2}$ concentration, traits such as leaf area, shoot $\mathrm{N}$ content, plant height and root volume were found to have important roles in dry matter accumulation. However, further experiments are required in the field under natural conditions to verify these findings.

\section{Acknowledgements}

Isfahan University of Technology (IUT) is acknowledged for funding this project. The authors are grateful to the staff of the Department of Agronomy and Plant Breeding, especially to Mr. Emadi for his assistance in the climate chamber control operations. The authors would also like to extend their gratitude to Dr. Ezzatollah Roustazadeh from ELC, IUT, for editing the final English manuscript.

\section{References}

Ainsworth EA, LongSP (2005). What have we learned from 15 years of free air $\mathrm{CO}_{2}$ enrichment (FACE)? A meta analytic review of the responses of photosynthesis, canopy properties and plant production to rising $\mathrm{CO}_{2}$. New Phytologist 165(2):351-372. 
408

Ainsworth EA, Rogers A (2007). The response of photosynthesis and stomatal conductance to rising $\left[\mathrm{CO}_{2}\right]$ : mechanisms and environmental interactions. Plant, Cell \& Environment 30(3):258-270.

Amthor JS (1997). Plant respiratory responses to elevated $\mathrm{CO}_{2}$ partial pressure. In: Allen LH, Kirkham MB, Olszyk DM, Whitman CE (Eds). Advances in carbon dioxide effects research. American Society of Agronomy Special Publication (proceedings of 1993 ASA Symposium, Cincinnati, OH), Madison, WI: ASA, CSSA andSSSA pp 35-77.

Amthor JS (2001). Effects of atmospheric $\mathrm{CO}_{2}$ concentration on wheat yield: review of results from experiments using various approaches to control $\mathrm{CO}_{2}$ concentration. Field Crops Research 73(1):1-34.

Arp W (1991). Effects of source-sink relations on photosynthetic acclimation to elevated $\mathrm{CO}_{2}$. Plant, Cell \& Environment 14(8):869875.

BarnabyJY,ZiskaLH(2012). Plant responses to elevated $\mathrm{CO}_{2}$. eLS.

Bencze S, Bamberger Z, Janda T, Balla K, Varga B, Bedő Z, Veisz O (2014). Physiological response of wheat varieties to elevated atmospheric $\mathrm{CO}_{2}$ and low water supply levels. Photosynthetica 52(1):71-82.

Bourgault M, Dreccer MF, James AT, Chapman SC (2013). Genotypic variability in the response to elevated $\mathrm{CO}_{2}$ of wheat lines differing in adaptive traits. Functional Plant Biology 40(2):172-184.

Cai C, Yin X, He S, Jiang W, Si C, Struik PC,Luo W,LiG, Xie Y, Xiong Y, Pan $G$ (2016). Responses of wheat and rice to factorial combinations of ambient and elevated $\mathrm{CO}_{2}$ and temperature in FACE experiments. Global Change Biology 22(2):856-874.

Chaudhuri U, Burnett R, Kirkham M, Kanemasu E (1986). Effect of carbon dioxide on sorghum yield, root growth, and water use. Agricultural and Forest Meteorology 37(2):109-122.

Chaudhuri U, Kirkham M, Kanemasu E (1990). Root growth of winter wheat under elevated carbon dioxide and drought. Crop Science 30(4):853-857.

Cheng J-f, Jiang H-y, Liu Y-b, Dai T-b, Cao W-x (2011). Methods on identification and screening of rice genotypes with high nitrogen efficiency. Rice Science 18(2):127-135.

Fernandez GC (1992). Effective selection criteria for assessing plant stress tolerance. Adaptation of food crops to temperature and water stress pp 13-181992257270.

Fischer R, Byerlee D, Edmeades G (2014). Crop yields and global food security. ACIAR: Canberra, ACT.

Fischer R, Maurer R (1978). Drought resistance in spring wheat cultivars. I. Grain yield responses. Crop Pasture Science 29:897-912.

Hoagland DR, Arnon DI (1950). The water-culture method for growing plants without soil. Circular. California Agricultural Experiment Station $347(2)$.

IPCC (2014). Climate change 2014: synthesis Report. Contribution of working groups I, II and III to the fifth assessment report of the intergovernmental panel on climate change. In: Edenhofer O, PichsMadruga R, Sokona Y, Farahani E, Kadner S, Seyboth K, et al., Minx JC (Eds). Cambridge University Press, Cambridge, United Kingdom and New York, NY,USA.

Jaynes D, Kaspar T, Colvin T, James D (2003). Cluster analysis of spatiotemporal corn yield patterns in an Iowa field. Agronomy Journal 95(3):574-586.
Jia Y, Tang S, Ju X, Shu L, Tu S, Feng R, Giusti L (2011). Effects of elevated $\mathrm{CO}_{2}$ levels on root morphological traits and $\mathrm{Cd}$ uptakes of two Lolium species under $\mathrm{Cd}$ stress.Journal of Zhejiang University Science B 12(4):313-325.

Kant S, Seneweera S, Rodin J, Materne M, Burch D, Rothstein SJ, Spangenberg G (2012). Improving yield potential in crops under elevated $\mathrm{CO}_{2}$ : integrating the photosynthetic and nitrogen utilization efficiencies. Frontiers in Plant Science 3:162.

Kazemi Sh, Eshghizadeh HR, Zahedi M (2018). Responses of four rice varieties to elevated $\mathrm{CO}_{2}$ and different salinity levels. Rice Science 25(3):142-151.

Khajehpour M (2013). Cereal crops. Jahad Daneshgahi (IUT) Press. Isfahan, Iran. In Farsi (Persian) language.

Li F, Kang S, Zhang J, Cohen Sh (2003). Effects of atmospheric $\mathrm{CO}_{2}$ enrichment, water status and applied nitrogen on water and nitrogenuse efficiencies of wheat. Plant and Soil 254(2): 279-289.

Long SP, Ainsworth EA, Rogers A, Ort DR (2004). Rising atmospheric carbon dioxide: plants FACE the future. Annual Review of Plant Biology 55:591-628.

Madhu M, Hatfield JL (2014). Interaction of carbon dioxide enrichment and soil moisture on photosynthesis, transpiration, and water use efficiency of soybean. Agronomic Science 5(5) 410-429.

Manderscheid R, Weigel H(1997). Photosynthetic and growth responses of old and modern spring wheat cultivars to atmospheric $\mathrm{CO}_{2}$ enrichment. Agriculture, Ecosystems \& Environment 64(1):65-73.

Mitterbauer E, Bender J, Erbs M, Enders M, Habekuß A, Weigel H-J, Ordon $F$ (2014). Growth and genome analyses of 100 different winter barley genotypes exposed to future $\mathrm{CO}_{2}$ concentrations under field conditions. In: Pekrun C, Wachendorf M, Francke-Weltmann L. (Eds). Tagung der Gesellschaft für Pflanzenbauwissenschaften e. V. mit der Max-Eyth-Gesellschaft Agrartechnik VDI-MEG, 16. bis 18. September 2014, Wien - 'Technik in der Pflanzenproduktion', Kurzfassungen der Vorträge und Poster. VerlagLiddy Halm, Göttingen pp 172-173.

Musgrave ME, Strain BR (1988). Response of two wheat cultivars to $\mathrm{CO}_{2}$ enrichment under subambient oxygen conditions. Plant Physiology 87:346-350.

Novozamsky I, Eck R, Van Schouwenburg JC, Walinga I (1974). Total nitrogen determination in plant material by means of the indophenolblue method. Netherlands Journal of Agricultural Science 22:3-5.

Pal M, Rao L, Jain V, Srivastava A, Pandey R, Raj A, Singh K (2005). Effects of elevated $\mathrm{CO}_{2}$ and nitrogen on wheat growth and photosynthesis. Biologia Plantarum 49(3):467-470.

Pang W, Crow W, Luc J, McSorley R, Giblin-Davis R, Kenworthy K, Kruse J (2011). Comparison of water displacement and WinRHIZO software for plant root parameter assessment. Plant Disease 95(10):1308-1310.

PocketbookFS (2015). World Food and Agriculture 2015. Rome:FAO.

Reddy KR, Hodges H (2000). Climate change and global crop productivity. CABI

Rogers H, Peterson C, McCrimmon J, Cure JM (1992). Response of plant roots to elevated atmospheric carbon dioxide. Plant, Cell \& Environment 15(6):749-752 
Seneweera S, Posch S, Norton R, Tausz M, Fitzgerald G, Korte Ch, Rebetzke G, Mollah M, BarlowS (2010). Differential response of wheat cultivars to elevated $\mathrm{CO}_{2}$ in Australian Grains Free Air Carbon dioxide Enrichment (AGFACE), 15th Australian Agronomy Conference, "Food Security from Sustainable Agriculture". Australian Society of Agronomy, Lincoln New Zealand.

Tans P (2016). Trends in atmospheric carbon dioxide. Earth System Research Laboratory, Global Monitoring Division.

TaubDR, WangX (2008). Why are nitrogen concentrations in plant tissues lower under elevated $\mathrm{CO}_{2}$ ? A critical examination of the hypotheses. Journal of Integrative Plant Biology 50(11):1365-1374.
Uprety D, Dwivedi N, Jain V, Mohan R, Saxena D, Jolly M, Paswan G (2003). Responses of rice cultivars to the elevated $\mathrm{CO}_{2}$. Biologia Plantarum 46:35-39.

Van der Kooi CJ, Reich M, Low M, Kok LJD, Tausza M (2016). Growth and yield stimulation under elevated $\mathrm{CO}_{2}$ and drought: A meta-analysis on crops. Environmental and Experimental Botany 122:150-157. 